\title{
Investigating Tasks and Teaching Methods for Adult Somali Refugees at a London Esol Centre
}

\author{
Ms. Charlotte Anyango Ong'anga \\ School of Humanities and Social Sciences \\ Jaramogi Oginga Odinga University of Science and Technology \\ P.O. Box 210 - 40601, Bondo, Kenya.

\section{Dr. Ajowi Jack Odongo} \\ School of Education \\ Jaramogi Oginga Odinga University of Science and Technology \\ P.O. Box 210-40601, Bondo, Kenya. jackajowi@yahoo.com
}

\section{Doi:10.5901/mjss.2013.v4n3p25}

\begin{abstract}
The influx of Somali refugees in the United Kingdom (UK) renders the country as the biggest host to one of the largest and longest established Somali communities in Europe. The fact that the refugees arrive in the UK with little or no previous knowledge of the English language, has made the investigation of English for Speakers of Other Languages (ESOL) literacy instructional techniques and methods a priority within the ESOL professional field. It is hoped that the free provision of English language programs to Somali adult refugees leads to improved settlement outcomes, however, it is argued that the delivery and instructional techniques may not always be sufficient to ensure effective and efficient integration, economic and social selfsufficiency or, indeed, to a feeling of 'belonging' in the host community. This study investigates the teaching methods and tasks used to teach refugees English at the X ESOL Learning Centre in London. It focused specifically on the Somali refugees. The objectives of the study are to determine the suitability of the tasks used to teach ESOL, the attitude of the learners towards the tasks and finally to make some recommendations. Two methods were used to achieve these objectives. An experiment was carried out where one half of the beginners class was exposed to a new teaching method and tasks while the other half carried on with the usual methods and tasks. The experiment lasted for fifteen weeks and tests were given before, during and after the teaching period. Questionnaires, interview and observation schedules were used to collect data on the attitudes of the learners towards the tasks. The results were that the test group learners performed way above the control group learners at the end of the experiment showing that the new methods introduced were superior to the usual methods at the Centre. Also the learners were far happier with their new tasks and they preferred them to the usual ones. Independent observers also noted that the learners were much happier and learnt better with the new tasks. The study therefore recommends that the new methods should be adopted for teaching English to the Somali refugees.
\end{abstract}

Keywords: Tasks, Teaching Methods and Adult Refugees

\section{Introduction}

This research investigates tasks and teaching methods for Somali refugee adult ESOL learners at 5E Limited College in London, England. Somali Democratic Republic is a country in the Horn of Africa bordering Djibouti in the northwest, Kenya in the southwest, Yemen and the Gulf of Aden in the north, Ethiopia to the west and Indian Ocean in the east. (Genocide Intervention Network, 2008).

Somalia has had a civil war since the early nineties when its first president Siyyad Barre was ousted from power. At the time of independence in 1960, Somalia was a model rural democracy in Africa. However, poor governance characterized by clanism and extended family loyalties; and conflicts finally led to the collapse of the government. Siyyad Barre the independence president was a dictator who oppressed his people. Most of his rule was characterized by torture, persecution and jailing of real and perceived political opponents. This was not confined to just political opponents but was extended to the rural population as well. According to the United Nations Development Programme human rights report the 21 years of Siyyad Barre had one of the worst human rights violation records in Africa. The Africa Watch Committee wrote in a report that "both the urban population and nomads living in the countryside [were] subjected to summary killings, arbitrary arrest, detention in squalid conditions, torture, rape, crippling constraints on freedom of 
movement and expression and a pattern of psychological intimidation." Amnesty International went on to report that torture methods committed by Barre's National Security Service (NSS) included executions and "beatings while tied in a contorted position, electric shocks, rape of woman prisoners, simulated executions and death threats."

Since the outbreak of the Somali Civil War in 1991 there has been no central government control over most of the country's territory. United Kingdom accepts refugees on a prima facie basis and has a rich infrastructure to facilitate the resettlement of refugees. The refugees have to assimilate into a new way of life, new environment, language barriers and xenophobia. English is the main language of both instruction and communication and the lack of knowledge of this language results in an uphill struggle for refugees in their quest for a healthy acculturation and ease to education. Since the war there has been movement of Somali refugees about the world and United Kingdom is not an exception. The major challenge that they have universally is the language barrier which limits them from acquiring the necessary privileges of education that they need. Only a few Somali Refugees are able to grasp English while others have to learn English prior to commencing their studies. Those who arrive already having some knowledge of English are able to progress with ease.

In the United Kingdom (UK), there is a large Somali community leaving in London. Studies confirm that London has the largest number of Somali refugees, followed by cities such as Birmingham, Liverpool and Cardiff (Home Office, 2006). Somali refugees find it more difficult to learn English and often take longer to learn English as a language. However, the researcher discovered that despite the fact that many Somalis have lived here for a couple of years, the majority have a poor grasp of the English language and in some cases, could not speak or understand the language at all. This could be attributed to the fact that Somalis are more collectivistic in contrast to the people in the UK who are more individualistic. This restricts their ability to interact with the wider community at large and hinders progress towards developing English language skills (Nielsen, 2004).

Most of the Somali refugees have minimum or no education background. Following the outbreak of the civil war in Somaliland in 1991, the task of running schools in Somalia was initially taken up by community education committees established in $94 \%$ of the local schools. Numerous problems had arisen with regard to access to education in rural areas and along gender lines, quality of educational provisions, responsiveness of school curricula, educational standards and controls, management and planning capacity, and financing.

Somali and Arabic are the official languages of Somalia, while English and Italian are believed to be second languages according to the Transitional Federal Charter of the Somali Republic (According to article 7 of The Transitional Federal Charter of the Somali Republic). The Somali language is the mother tongue of the Somali people. The Somali language is a member of the Cushitic branch of the Afro-Asiatic language family, and it is the best documented of the Cushitic languages, with academic studies of it dating from before 1900.The Somali alphabet is the most widely used, and has been the official writing script in Somalia since the government of former President of Somalia Siyyad Barre formally introduced it in October 1972. (Metz 1992).

Arabic is spoken in Somali as an official national language in addition to the Somali language. Arabic is used due to centuries-old links with the Arabic countries. English is widely used and taught but due to interruption in the sector of Education, most Somalis do not have a firm grip of the language. Italian used to be a major language, but its influence significantly diminished following independence. It is now most frequently heard among older generations. This means that most Somalis arriving in Britain are not familiar with the structure of English or any other European language. (Diriye 2002).It is very essential for the adult Somali refugee to learn English despite the fact that there is a huge difference between Cushitic languages (Somali) and West Germanic languages (English). Somali is an agglutinative language, using a number of markers for case, gender and number. Other characteristic differences between Somali and most IndoEuropean languages include multiple forms of most personal pronouns, the use of particles to signify the focus of a sentence, extensive use of tone to denote differences in case and number, and gender polarity which is the gender of many words is different in the singular and plural forms. (Saheed 1987).

Thus the Somali refugees face a big challenge in trying to acquire English language

By enrolling at the college to learn ESOL, the refugees secure their housing benefits and they also obtain free bus-passes. The X Learning Centre is an ESOL Institution in north London Haringey Borough. It offers Skills for Life curriculum for both numeracy and ESOL courses. The government has used Skills for Life programme as a strategy for improving adult literacy, numeracy and ESOL skills in England, Wales and Northern Ireland. From September 2004, all qualifications for adult learners of English in the state sector which relate to the strategy must be based on the Adult ESOL Core Curriculum - a development of the National Standards for Adult Literacy - and accredited by the Qualifications and Curriculum Authority (QCA). 
A full range of Certificates in ESOL Skills for Life is offered. These qualifications provide flexible assessment of ESOL learners in England, Wales and Northern Ireland, and reducing the workload of both teachers and administrators.

The Skills for Life Certificates are normally available at five levels - Entry 1, Entry 2, Entry 3, Level 1 and Level 2. They are wholly externally assessed, by trained and experienced examiners. The Skills for Life Certificates are also available on demand to suit the learner and the learning provider and are accredited by the QCA and funded by the Learning and Skills Council. They can be provided in every day of the year, except for the UK public holidays. The Skills for Life tests are designed for learners aged 14+ whose home language is not English, who are living or trying to settle in England, Wales and Northern Ireland. These ESOL learners may include refugees or asylum seekers, migrant workers, people from settled communities, and partners or spouses of people who are settled in this country for a number of years.

X ESOL Learning Centre also offers Job Search sessions and Employability Skills in which learners are taught how to be independent in job search and cope in job environment. They are taught CV writing skills, application letters and cover letters writing, and given hints on interviews. Information Technology courses are also offered to learners. The educational level of the tutors in this college range from CELTA/DELTA certificates to Masters in TESOL. The tutors are trained to deliver professionally and also treat their clients respectfully. There are different tutors for literacy, IT, ESOL, Numeracy and a job search adviser from London Job Centre Plus.

\section{Statement of the Problem}

Often when a people have to leave their country as refugees fleeing war and other types of persecution, they have very little choice if at all as to where they will be hosted. In many cases refugees from Africa end up in the western countries where they have to learn the language of the host country. Somali refugees who have found themselves in London have to learn English and this study aims to determine the suitability of the tasks that are used to teach these refugees English.

\subsection{Hypothesis}

The hypothesis of this study is that the tasks used to teach adult Somali ESOL students are not suitable therefore leading to poor performance.

\subsection{Objectives}

This study had the following objectives:

a. To determine the suitability of methods and tasks being used to teach Somali ESOL learners at X ESOL learning Centre.

b. To determine the attitude of the adult Somali ESOL learners towards their learning tasks.

c. To recommend tasks and teaching methods, more suitable for the ESOL learners.

\section{Research Methodology}

The research samples were adult Somali refugee ESOL learners at X ESOL Learning Centre in London. All the twenty entry one clients were sampled. These learners had low academic achievement because as noted earlier on, there is hardly any stable educational system in Somalia due to the civil war and hence it has a large unschooled adult population. The study subjects were a mixed group of eight women and twelve men of between ages 30-55.

The study subjects were fluent only in the L1 which is Somali and had had no education either back in Somalia or in the UK. Basically they found it difficult to utter English sounds although through some basic learning of English they could utter such phrases as "I come from Somalia".

This was an experimental type of research where there was a test and a control group. The new teaching method was applied to the test group who were taught by the researcher. The control group on the other hand was exposed only to the normal teaching method and materials and were taught by a regular teacher at the institution. The experiment went on for 15 weeks of twenty hours of teaching per week.

The X ESOL Learning Centre used the Skills for Life entry 1 book and its cassette for listening skills. They also used New Headway Beginners Students' Book. The approaches used were communicative language teaching, audiolingual and task-based approaches. Translation was allowed in class, especially to learners who had a problem 
understanding the simplest of instructions. "Hang-man" was a common game used to end lessons and thus repetition when it came to games. The learners were taken out for trips to libraries, museums, cinema and picnics once in a while.

The new teaching method that the test group was exposed to was a hybrid of more than one teaching method blended with humanistic approaches to teaching refugee adults. Each method was employed depending on the teaching objectives for a specific lesson. The teacher worked on the learners' self-esteem with each topic handled and this was mostly done through activities like discussions, role plays and group work. The researcher used a variety of English Grammar books to tailor materials to suit the level she was teaching rather than following the curriculum in certain specific entry $1 \mathrm{ESOL}$ books. The learners were given easy and interesting tasks as the first activities in the morning to introduce the lessons. For instance, dictation exercises to improve spelling or telephone conversation role-play. The researcher gave the learners a variety of activities and avoided repetition of games. Activities involved ranged from individual work, pair work to group work. There were also listening exercises which were done through the use of cassettes. The researcher made the use of a variety of learning materials in delivering the course; they included charts, projectors, colourful pictures and authentic materials.

Once in a while, the learners went for trips to places like libraries, cinema, museums and picnics. There was no translation whatsoever in class. Only English was to be strictly spoken. The learners were given quizzes after every four weeks to check if they understood whatever they learnt in class or during trips.

This method was therefore significantly different from the normal one used in the centre. Diagnostic, mid-term and final examinations were administered to both groups. The mid-term test was administered after eight weeks and the final examination on the fifteenth week.

Questionnaires were administered to five members of both the test group and the control group and the same five were also interviewed. The five from each class were selected on merit. They could follow simple instructions on the questionnaires with minimal assistance.

In order to gather data for this study, permission was sought from the institutional authority. The institution made arrangements to contact both the students and the staff and made them available.

Three types of instrument were used to collect data. A questionnaire was constructed for collecting data at the end of each unit and was filled by 5 learners from each class (test class and control class). The second instrument was an interview schedule. The same 5 learners from each class were interviewed and the two teachers who observed the taught lessons were interviewed too. The third data collection tool was an observation schedule that was used by two ESOL tutors. Two regular teachers at the institution were given the lesson plans and materials a day before the lesson was taught. They observed the lesson, taking note of how the researcher followed each step of the lesson plan and the response by the learners and then they gave their views after the lesson. The teachers observed the researcher as she delivered what was already on the lesson plan. Their views were solicited on the tasks and the teaching method.

The 5 point Likert scale questionnaires were self-administered; care was taken to give clear and explicit instructions in very simple English. The questionnaires were filled by 5 learners from each group. One of the ESOL tutors at the college gave them any assistance they needed much as they easily understood most of the questions on the questionnaires. The questions asked on the questionnaire depended on the topics tackled in each unit.

The interviews were carried out by a regular member of the teaching staff at the Learning Centre, who was never involved in the teaching of neither the test class nor the control class. The interviewer asked the same questions to 5 learners from both the test class and control class (the same 5 learners from each class, who filled the questionnaires).

The responses from the interviewees were analyzed and conclusions were drawn. The conclusions drawn were presented on pie charts. The interview questions were tailored to gather information about the teaching methods that were used in class and the activities that were interesting and those that were not. The learners also talked about what activities they would prefer more of or less of in class.

The task syllabus was created in synthetic syllabus with focus on forms approach. The designed tasks targeted the learner's interests and also raised their awareness of regional, social and educational programs for example after they learnt adjectives, they were asked to describe arrears they lived in London. For instance, using adjectives to describe places like, Tottenham or Finsbury Park. So the learners had to use adjectives like clean, dirty, safe, dangerous, quiet, noisy and the likes.

The content of the task targeted the learners' real world issues which they encountered outside classroom. For example, a role play in an emergency where one needs to call an ambulance. The students pair up; one becomes the victim while the other becomes the ambulance centre. The focus is on the vocabulary and also how to give an address. Each task required approximately 60 minutes to complete and culminated in a written report and an individual and group oral presentation. 
In the course, some of listening and reading materials were incorporated from Skills for Life and Headway course books. The researcher selected excerpts from the textbooks that complemented the content of the tasks as well as the knowledge and skills required to complete the tasks. The researcher also created supplementary materials to explicitly introduce teaching strategies that were useful for the completion of the tasks. The target teaching strategies involved teaching according to the individual learner's needs and learning styles.

Since the course employed a focus-on-form approach, it was necessary for the researcher to ensure the provision of explicit information about the language forms relevant for each task as a resource material to the learners. The learners could consult the materials for additional knowledge about language structure. The course assessment included 3 oral and a written task performances, the first of which was the Skills for Life Initial Assessment, given to the learner as they began the course. Others included two periodic in-class quizzes done every four weeks; and a final examination which consisted of tasks almost similar to those done initially in class but not the same. The periodic in class quizzes were only done in the test class. The researcher gave the learners the quizzes to confirm if they understood whatever they had been taught in class and also whatever they had learnt from trips.

The study drew on data from three primary and two secondary sources to gain a rich understanding of what is suitable for the learners in terms of teaching methods and tasks. The data for this study included task evaluation, observations, course evaluation and interviews. According to Denzin and Lincoln (2000) a qualitative research adopts a cyclic, recursive approach to the data analysis so that preliminary reflections guide the subsequent data collection that helps to refine reflections.

Robson (1993) asserts that irrespective of whether the study is qualitative or quantitative, a major task is to find answers to the researchers' questions. He further agues that data interpretation and analysis involves making sense of what people have said, looking for patterns, putting and integrating together what is said in one place into another place and interpreting what different people have said. Therefore, the data collected from the responses in this study was analyzed through tabulation of the results, content analysis and discussion. Descriptive statistics involving percentages were also used to present the data collected in this case study.

\section{Results and Discussions}

\subsection{The Diagnostic Test Results}

At the onset of the students' registration, they were given diagnostic tests which were to confirm the actual level of the learners. The alphabetical letters represent the 10 learners of each class and their diagnostic results. The test results showed that they were beginners. Table 4.1 and 4.2 below show the results of the test.

Table 4.1. Results of test group diagnostic test

\begin{tabular}{|c|c|c|c|c|c|c|c|c|c|c|}
\hline & $\mathrm{A}$ & $\mathrm{B}$ & $\mathrm{C}$ & $\mathrm{D}$ & $\mathrm{E}$ & $\mathrm{F}$ & $\mathrm{G}$ & $\mathrm{H}$ & $\mathrm{I}$ & $\mathrm{J}$ \\
\hline $\begin{array}{c}\text { Diagnostics } \\
\text { Test Class }\end{array}$ & $9 \%$ & $13 \%$ & $11 \%$ & $17 \%$ & $12 \%$ & $13 \%$ & $10 \%$ & $20 \%$ & $19 \%$ & $12 \%$ \\
\hline Mean Grade (13.6\%) & & & & & & & & & & \\
\hline
\end{tabular}

Table 4.2. Results of control group diagnostic test

\begin{tabular}{|c|c|c|c|c|c|c|c|c|c|c|}
\hline & $\mathrm{A}$ & $\mathrm{B}$ & $\mathrm{C}$ & $\mathrm{D}$ & $\mathrm{E}$ & $\mathrm{F}$ & $\mathrm{G}$ & $\mathrm{H}$ & $\mathrm{I}$ & $\mathrm{J}$ \\
\hline $\begin{array}{c}\text { Diagnostics Control } \\
\text { Class }\end{array}$ & $22 \%$ & $10 \%$ & $15 \%$ & $7.5 \%$ & $18 \%$ & $12 \%$ & $20 \%$ & $12 \%$ & $13 \%$ & $8 \%$ \\
\hline Mean Grade (13.75\%) & & & & & & & & & & \\
\hline
\end{tabular}

From the tables above, the results indicate a mixed ability class in both the test class and control class. Mixed ability in this case means, in each class, there are high scorers and low scorers. In the test class for instance, the top students had $20 \%, 19 \%$ and maybe $17 \%$. The lowest had $11 \%$ and $9 \%$. The control class is marginally better than the test group. Results range from as low as $9 \%$ to a high of $20 \%$ for the test class and a low of $7.5 \%$ to a high of $22 \%$ in the control class. The learners were all beginner level as confirmed from their diagnostic results.

Most of the learners in both the test and control classes were consolidating in the listening part of the test but emerged in both writing and reading skills. Emerging, consolidating and established were the three main classifications of 
grades. Established learners were the top scorers, followed by the average students (consolidating) and the lowest in performance were said to be emerging. Most of the learners, as mentioned earlier on were consolidating in the speaking skills and this was so because the learners were able to speak some basic words in English. They could understand simple instructions like 'what is your name? Where do you come from?' are you married? They could also greet in English.

There was a lack of motivation evident on the first days of the course, the learners attended classes late and left earlier than the expected time, they sat as they wished and interacted less. They spoke with their peers in Somali and most attended class irregularly, listing so many excuses to absent themselves from class. All learners, regardless of age, have to be disciplined in order to be successful in the course. The learners did not perform well due to a negative attitude in class due to: little experience of school or learning, so not familiar with the conventions of educational politeness; low self-esteem academically and therefore low expectation of personal success in L2 leading to a lack of motivation to try; external stress and pressure making the ESOL lessons seem not important.

The researcher then came up with strict rules which according to the interview were received positively by most of the learners. Some of the learners appeared rebellious in the first few days when the new rules were being implemented but soon they discovered that it was for their own good. Adult learners are thus different from younger learners because they often have a clear understanding of why they are learning and what they want to get out of it Harmer (1998).

The learners had to strictly attend their classes punctually and regularly. No student would leave the class before 3:30 pm, the official ending time. Only English was to be spoken in class. There was no translation whatsoever. The teacher gave the learners a short break between the lessons to care for any needs they would have. The researcher worked on the motivation of the learners by applying the teaching methods she regarded as more suitable and also by using the "more appropriate" tasks.

The learners then got motivated gradually from the interactive lessons. They actively participated in the tasks they were assigned and they also claimed to like the way their teacher taught them. The learners interacted freely in their discussion groups, became friendly to each other and enjoyed learning more about each other. The learners appreciated the fact that they had to strictly speak in English. This greatly improved their speaking skills and also built their confidence. Seating arrangement was the teacher's role depending on the objectives of that particular lesson. This blocked segregation in class and instead it promoted a harmonious learning environment. The learners treated each other as equals, both women and men, and they were very cooperative in doing the tasks. They shared their experiences.

After 8 weeks in the course, the learners were given mid-term test. All the 20 learners from both test and control classes were given the same test at the same time. This was to examine the progress in each learner. This test was set by all the teachers of this level. The results of the test are laid out in tables 4.3 and 4.4

Table 4.3. Results of mid-term test for the test group.

\begin{tabular}{|c|c|c|c|c|c|c|c|c|c|c|}
\hline & A & B & C & D & E & F & G & H & I & J \\
\hline Diagnostics Test Class & $9 \%$ & $13 \%$ & $11 \%$ & $17 \%$ & $12 \%$ & $13 \%$ & $10 \%$ & $20 \%$ & $19 \%$ & $12 \%$ \\
\hline Mid-Term & $13 \%$ & $21 \%$ & $15 \%$ & $32 \%$ & $40 \%$ & $26 \%$ & $17 \%$ & $52 \%$ & $36 \%$ & $30 \%$ \\
\hline $\begin{array}{c}\text { Mid-Term Mean Grade } \\
(28.2 \%)\end{array}$ & & & & & & & & & & \\
\hline
\end{tabular}

Table 4.4. Results of each learner for Control class in details.

\begin{tabular}{|c|c|c|c|c|c|c|c|c|c|c|}
\hline & A & B & C & D & E & F & G & H & I & J \\
\hline $\begin{array}{c}\text { Diagnostics Control } \\
\text { Class }\end{array}$ & $22 \%$ & $10 \%$ & $15 \%$ & $7.5 \%$ & $18 \%$ & $12 \%$ & $20 \%$ & $12 \%$ & $13 \%$ & $8 \%$ \\
\hline Mid-Term & $20 \%$ & $15 \%$ & $12 \%$ & $12 \%$ & $24 \%$ & $16 \%$ & $26 \%$ & $14 \%$ & $13 \%$ & $9.5 \%$ \\
\hline $\begin{array}{c}\text { Mid-Term Mean Grade } \\
(16.15 \%)\end{array}$ & & & & & & & & & & \\
\hline
\end{tabular}

The results of the mid-term test show an improvement in both groups. However, the most obvious improvement is in the mean of the test group and also in the range. The mean of the test group in this test is way above that of the control with a wide margin. The learners in the test class have all gained better grades than their initial performance. Some have 
improved way better than the others. The performance in the control class is a little different from the one in the test class. Some learners have improved; some have performed poorer while some have retained their initial grades.

The possible reason for the better grades obtained in the mid-term test by the test group is, the test group learners had changed their attitude towards learning English and were more positive. They seemed to have worked on their selfesteem and built confidence in the language. Since they had been interacting in English, they improved greatly in their speaking skills. As Long's Interaction hypothesis claimed, learners need to interact in the target language in order to perform well in it. In case of a communication breakdown, they should negotiate for meaning and hence develop a comprehensive input.

Maslow (1987) suggested that self-esteem is a necessary deficiency need which has to be met before aesthetic or cognitive needs could be engaged as mentioned in the literature review. The teacher, while designing activities for the learners, bore in mind the fact that the students' state of mind and their response to the tasks assigned are central to the success or failure in second language acquisition. The adult Somali refugees have gone through bitter experiences. They have experienced torture due to the political unrest in their country. Some women, according to the reports mentioned in the background, were raped. Such painful experiences make the victims develop low self-esteem. The student's feelings are as important as their cognitive abilities. The teacher recognized and understood the students. The students were helped to develop pride in themselves through the use of tasks. When teaching 'the family tree', the learners were asked to cut pictures given to them by the researcher, stick them using glue on a cartridge and build a family tree. The pictures were of all ages, very old men and women to indicate great grand parents or grandparents and younger men and women. The Somali refugees adore clanship and relationship ties. They live in large numbers of family members and clan members and as such it is vital for them to know the English words to refer to those they live with. From the questionnaires, they valued the fact that they were taught relevant topics.

The learners consulted each other for appropriate vocabulary and spelling. They were then asked to discuss their own family trees, whether they had great grand parents or grand children, uncles or aunties. One of the women talked about her father having four wives and 21 children. The feedback was positive. Most of the learners discussed freely apart from few who appeared a bit reserved. The students appeared to enjoy and be very motivated by the task and did so well in the vocabulary (such as, mother-in-law, mothers-in-law, great-grandson and grandfather) involved in the family tree. If a student likes the type of tasks assigned to them, chances are high that they will perform exceptionally well. So the teacher designed interesting tasks for the learners. (See appendices 3 and 4 for examples).

The teacher played a major role in helping the students to 'notice' in the target language by drawing their attention to the relevant features applying directly to them. One of the grammar books that the teacher used was New Headways Beginner by Soars. The book is an admirably simple-work, eloquently written with stimulating tasks and has a section "Grammar Spot" which makes "noticing" much easier for the learners. The teacher drew this idea from Schmidt's (1990) notion of noticing a language, whereby the teacher is suppose to assist her learners in noticing by drawing their attention to it. The researcher also drew the attention of the learners to forms through the use of dictation exercises and sentence construction. At the end of each unit, a quiz was given to the learners to test their understanding.

\subsection{The Final Evaluation}

The final evaluation was done on the fifteenth week which was the end of the course. All the students sat for this exam under strict invigilation by unfamiliar teachers (teachers of other entry levels). The examination was not set in the college but by an examination body approved by the examination council. Both the marker and the verifier were external. The only material that was used by the learners in the examination was an English Dictionary. The results are presented in the figure below.

Table 4.5. Results analysis for Test class.

\begin{tabular}{|c|c|c|c|c|c|c|c|c|c|c|}
\hline & $\mathrm{A}$ & $\mathrm{B}$ & $\mathrm{C}$ & $\mathrm{D}$ & $\mathrm{E}$ & $\mathrm{F}$ & $\mathrm{G}$ & $\mathrm{H}$ & $\mathrm{I}$ & $\mathrm{J}$ \\
\hline $\begin{array}{c}\text { Diagnostics } \\
\text { Test Class }\end{array}$ & $9 \%$ & $13 \%$ & $11 \%$ & $17 \%$ & $12 \%$ & $13 \%$ & $10 \%$ & $20 \%$ & $19 \%$ & $12 \%$ \\
\hline Mid-Term & $13 \%$ & $21 \%$ & $15 \%$ & $32 \%$ & $40 \%$ & $26 \%$ & $17 \%$ & $52 \%$ & $36 \%$ & $30 \%$ \\
\hline Final Exams & $42 \%$ & $50 \%$ & $52 \%$ & $44 \%$ & $36 \%$ & $56 \%$ & $49.5 \%$ & $72 \%$ & $69 \%$ & $53 \%$ \\
\hline $\begin{array}{c}\text { Final Exams Mean Grade } \\
(52.35 \%)\end{array}$ & & & & & & & & & \\
\hline
\end{tabular}


Table 4.6. Results analysis for Control class.

\begin{tabular}{|c|c|c|c|c|c|c|c|c|c|c|}
\hline & $\mathrm{A}$ & $\mathrm{B}$ & $\mathrm{C}$ & $\mathrm{D}$ & $\mathrm{E}$ & $\mathrm{F}$ & $\mathrm{G}$ & $\mathrm{H}$ & $\mathrm{I}$ & $\mathrm{J}$ \\
\hline $\begin{array}{c}\text { Diagnostics } \\
\text { Control Class }\end{array}$ & $22 \%$ & $10 \%$ & $15 \%$ & $7.5 \%$ & $18 \%$ & $12 \%$ & $20 \%$ & $12 \%$ & $13 \%$ & $8 \%$ \\
\hline Midterm & $20 \%$ & $15 \%$ & $12 \%$ & $12 \%$ & $24 \%$ & $16 \%$ & $26 \%$ & $14 \%$ & $13 \%$ & $9.5 \%$ \\
\hline Final Exams & $51.5 \%$ & $32 \%$ & $16 \%$ & $14.5 \%$ & $37 \%$ & $22 \%$ & $25 \%$ & $29 \%$ & $18 \%$ & $12 \%$ \\
\hline $\begin{array}{c}\text { Final Exams Mean Grade } \\
(25.7 \%)\end{array}$ & & & & & & & & & \\
\hline
\end{tabular}

As the tables above indicate the mean grade of the test group is twice that of the control group. Whereas the mean grade of the test class is $52.35 \%$, that of the control group is $25.7 \%$. Performance has increased tremendously in the test class as compared to the control class. This means that learning was much better in the test group. Although the groups were made up of separate individuals, all the students had had a similar language profile on entry in terms of their overall test score and students had been allocated to classes randomly, thus no kind of pre-selection beyond identifying them at beginner level had gone on prior to teaching the two groups. The fact that the test group outperformed the control group by such a big amount suggests that the teaching methods and tasks used with the test group were superior to the ones that were used with the control group in terms of promoting student motivation and inspiring students to learn.

Authentic materials are understood as materials which are not produced for the purpose of language teaching, but are produced for some other purpose in the real world. Authentic texts are important more so to the non-academic Somali refugees because it connects grammar to the real world. The adult Somali refugee in this college is not learning English in order to be a teacher, or a doctor but to be able to adapt well to the new environment and maybe find a job like cleaning, housekeeping or kitchen assistant depending on the individual's interest. Authentic materials are very relevant to them. The learners need to know how to interpret information passed through flyers or advertisements on boards. They need to know how to fill forms (can be change of General Practioner forms or job application forms) they need to know how to conduct a telephone conversation (with an employer for instance, or calling ambulance or police) in which case role play would be suitable. The researcher used several authentic materials in delivering the cause. For instance, a map of the Borough was used in teaching Directions. Apart from learning the appropriate vocabulary for directions, the learners also understood how to read and interpret maps.

The Critical Period Hypothesis (CPH) according to Genesee (1998), states that there is a biologically determined period of life when language can be acquired more easily and beyond which time language is increasingly difficult to acquire and this hypothesis not only applies to first language acquisition, but also to second language acquisition. Penfield and Lenneberg (1998) discussed two reasons why language acquisition is difficult after puberty; the plasticity of the brain is lost at puberty, after which complete or native-like mastery of languages, first or second, is difficult and unlikely. This plasticity assigns functions to different areas of the brain and cannot be changed. Contrasting to what the two linguists suggested, is the fact that the adult Somali refugee learners, acquired language with less strain. The teacher used techniques which gave positive results. The researcher believed in her students. She did not make such assumptions as the learner being able or unable to successfully complete a task. Instead the researcher developed a positive attitude towards her learners and believed in them. This made it easier for the teacher to correct errors. She viewed an error as an opportunity to discover what needs to be re-taught in a different style if possible so that the learners can understand properly.

The syllabus designer according to Nunan (1989) needs to consider the following factors when selecting and grading. For instance, easier things are to be taught first and then the level of difficulty is increased as the students' language level rises. For instance, when teaching syllables, stress and spellings, the researcher introduced words with one syllables first, before handling those with more syllables, then to stress and spelling. This makes it easier and faster to understand. The learners, by the end of the course could spell a majority of words on personal information. Parts of speech were taught on their own and not introduced all at the same time. The researcher began by introducing nouns, discussed it well with the learners and confirmed that they understood the concept by giving a quiz.

Task based learning according to Ellis (2003), acknowledges language as a tool for communication. A task based approach is more learner-centered than teacher-centered. Since the adult learners can apply abstract thinking, the researcher engaged them in activities which triggered them into using their thoughts and experiences. This was done with so much care, so that not much was mentioned to do with migration, wars and no mention completely of the current situation in Somalia. This was done to care for the emotions of the learners. The teacher did a minimal supervision and the learners they were actually given room to imaginatively tackle the tasks on their own. 


\subsection{Learners' Attitudes towards the New Tasks}

Students from both classes were asked to fill questionnaires and were given minimal assistance. An objective of the study was to find out the learners' attitude towards the teaching methods and tasks presented to them. This was to indicate their attitude towards both the tasks and teaching methods that were used. In both the test class and the control class, learners filled a simple questionnaire. One of them was a closed ended question type with some YES/NO questions and the other was scales questions. (See appendix 1 and 2 respectively)

The questionnaire on appendix 1 is one of the questionnaires filled by the students at the end of a unit. Out of the ten students, 7 students indicated that they enjoyed group work activities more than individual work. This is so because; they do not take responsibility of poor performance while in groups. Most members of those groups hence became very dormant and let the few others to take charge of everything. As a result, only the few active ones performed well when quizzes were brought. Due to that reason, the researcher, having looked at this questionnaire, decided that the learners had to do more of individual work than group work and group work was done in small manageable groups and responsibility had to be divided and shared fairly among all, the members. Dormant members were given more work to do on their own. Group work provided them with a platform with which they could share their different experiences, relating them to the topics they were to tackle. Hence, they bonded with their mates and made themselves homes away from their homes.

The questionnaire on appendix 2 was filled by all the 20 learners who participated in this study. It was very interesting to note that all the ten students in the test group ticked yes on the first question (classes began on time), while 6 students in the control class ticked yes for the same. This indicated that the attitude of learners in the test class had changed to positive, they were more motivated and they attended their classes punctually.

Too much walking in and out of the class is not only dangerous to the learners but also dangerous to the teacher. Learners should be trained to keep their calm until the expected or agreed times for breaks. None of the learners in both the test and control groups needed more breaks in between the lessons. They were contented with the breaks they already had.

Most students in both classes indicated that they enjoyed, afternoon games, role-playing and interclass competitions. Some learners ticked NO for classroom presentations, probably due to shyness or maybe low self-esteem. Most students ticked YES, they felt their English was better than when they began the course. This questionnaire was filled after the midterm exams were done, that was the eighth week.

All the learners of the test group as reflected on the questionnaires appreciated and enjoyed the activities and approaches that the researcher used. The learners had a positive attitude towards the tasks and teaching methods and this is the reason why they performed well.

\subsection{Interviews}

Five learners from both the test class and control class were interviewed by teachers who taught neither of the participating groups (test and control groups). The interview questions were tailored to gather information about the teaching methods that were used in class and the activities that were interesting and those that were not. They were also to talk about what they would prefer more of and what they would prefer less of in class. They were supposed to selfasses their performance based on their results and conclude if they progressed or not and the possible contributing factors.

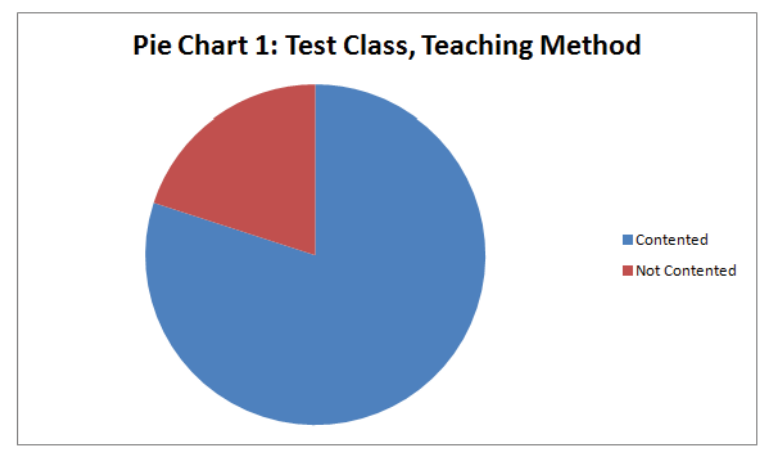


The interview results indicated that the learners in the test class had generally acquired confidence in themselves and were aware of their progress in each test that they did. According to Pie chart 1 above, 4 learners out of the 5 who were interviewed indicated that they were contented with the teaching method the researcher used.

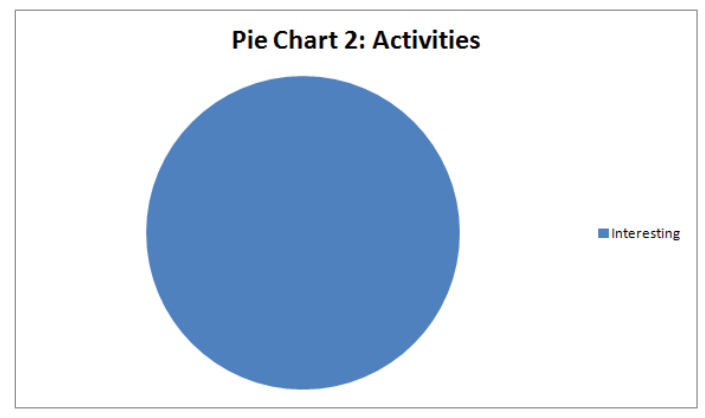

All the interviewees agreed that the activities were interesting as indicated in pie chart 2 above.

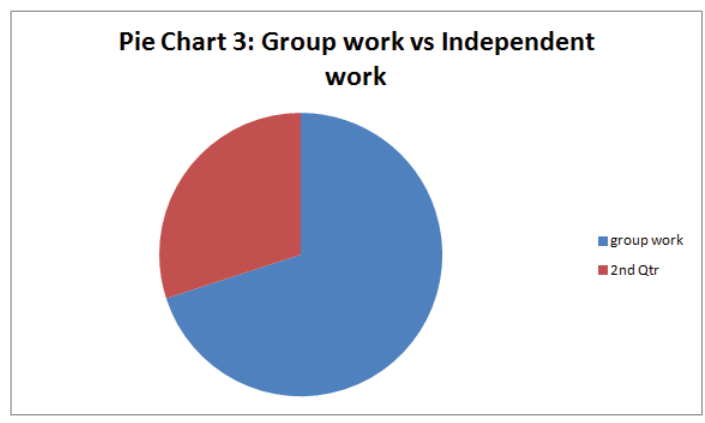

The pie chart above indicates that more learners preferred group work activities to independent work. 3 of the learners preferred more of group work activities to independent work while 2 learners preferred independent work. Most learners appear to prefer group work activities to independent work because they can easily remain passive in group work and not strain ensuring the task is complete. Most of them use groups to hide from active participation while some genuinely like to interact in the group work activities. 4 of the learners

The interview results indicated that the learners in the test class had generally acquired confidence in themselves and were aware of their progress in each test that they did. They also had a positive attitude towards both the tasks and teaching methods used in their class.

\subsection{Course Assessment by Staff}

The members of the teaching staff who had observed some sessions of both the teachers and gave their feedback concerning the tasks and teaching methods that were used by each teacher. They keenly made judgments based on student attitudes and motivation and also the organization and delivery of a lesson to individual learners. From their observation, it was evident that the learners showed contentment in the course. The lessons were delivered well and the students enjoyed them.

\subsection{Personal Reflection}

The researcher observed the learners in both classes, analyzed their performance and concluded that, the approaches that had been used in teaching were so far the most suitable for the adult Somali refugees in that college. 


\subsection{Findings}

In terms of the first research question; what is the attitude of the adult Somali ESOL Learners towards the tasks used to teach them English? Analysis of the data revealed that the test class learners engaged more actively in the tasks assigned to them compared to the control group learners. The test group learners had a positive attitude towards the tasks they were given. This can be evidenced from the data that was collected during the research.

The learners reported that the tasks assigned to them provided them with an opportunity to learn the language practically in both independent work and group work. They appreciated the fact that they had to use only English in class and a learner gave the following comment during an informal interview: "talking English with my friends in class has greatly improved my speaking skills".

The interview revealed that most of the learners in the test class were satisfied with the activities used by the researcher. They appreciated the fact that the researcher assigned them with new, interesting activities for each lesson. This can be achieved through proper planning of a lesson, so that a teacher does not lack ideas or activities for that matter and end up repeating games like word search or hung-man every time. This way, the learners start to associate such games with boredom and time-passing activities rather than as important activities for focus on forms.

In terms of the second research question which asked: Are the tasks and methods used in teaching the Somali refugees at X ESOL Learning Centre achieving the desired results? Data analysis has revealed that the tasks and methods used in teaching the adult Somali refugees at X ESOL Learning Centre are not achieving the desired results. 20 adult Somali refugee ESOL learners participated in the research. They were divided into two groups at random to form a test class and a control class. The test class was taught by the researcher while the control class was taught by a regular teacher at the ESOL Centre. Then all the learners did their diagnostic test and the results were recorded on tables (Chapter 4). The test class had a mean grade of 13.6 while the control class had a mean grade of 13.75 , slightly higher than that of the test class. Due to the application of what the researcher refers to as "suitable tasks and teaching methods", the test class learners improved and performed better than the control class in both midterm test and final evaluation.

\subsection{Discussion}

The findings have implications for the implementation of suitable tasks and teaching methods for adult Somali refugees at X ESOL Learning Centre. First, this study provides evidence that the tasks and teaching methods at X ESOL Learning Centre are not suitable for the adult Somali refugees.

The findings also indicate that teachers can respond to learners' needs by making use of many teaching approaches and tasks depending on the objectives of the lesson. An important methodological principle of task-based language teaching as explained by Long (2000) is focus on form, whereby attention to language forms is provided as a response to the learners' needs. It has been proved that if a teacher is put under pressure to follow the syllabus strictly, chances are high that they will pay less or no attention to language forms that arise incidentally during a lesson.

This study provides a useful reminder that adult learners, who have undergone trauma and other life threatening experiences like the adult Somali refugees, need suitable tasks and teaching method. The teacher has to satisfy the needs of a learner and this can be achieved through the understanding the learners and employing what suits them best.

\subsection{Evaluation}

This research was experimental. The researcher chose the experimental method to investigate the tasks and teaching methods used in the adult Somali ESOL class at a London ESOL Centre. Experimental researches are commonly used in behavioral sciences to provide an insight into cause-and-effect relationships. The cause of the underachievement of the adult Somali refugees in an ESOL Centre is use of unsuitable tasks and teaching methods. This method of research has a standardized procedure where by a problem has to be identified first, followed by a hypothesis and finally, recommendations to be given. This standardized procedure allows for a repeat if necessary. The experiment can be replicated to confirm the validity of a given claim. 


\section{Conclusions}

This research focused on the adult Somali refugees, because of a concern on their poor performance in ESOL at the $X$ ESOL Learning Centre. The first chapter began by discussing who the Somalis are and why they are refugees in the United Kingdom. Most of the Somalis ended up in UK as refugees due to the civil war that broke out in their country. Due to the civil war, there was a difficulty in accessing education facilities and thus a larger percentage of the Somali refugees have a poor educational background.

As seen earlier, many linguists and theorists have different beliefs about the adults and second language acquisition. While few linguists and theorists claim that acquisition becomes more difficult after puberty stage, most agree that language acquisition can occur at any age. Adult learners are actually said to be more determined in learning a second language than younger learners.

The kind of tasks and teaching methods at X ESOL Learning Centre proved to be unsuitable for the adult Somali refugees learning at the centre. The data collected through questionnaires, interviews and observations evidenced that; the adult Somali refugees perform exceptionally in ESOL when suitable tasks and teaching methods are employed. This can be achieved when the first step a teacher takes is to know and understand the learners. The ESOL text books on their own might be insufficient when it comes to individual learner needs hence it is better if the teacher tailors materials to satisfy the learner's exact needs.

\section{References}

Anderson, J. R. (1982) Acquisition of cognitive skill. Psychological Review

Ahmed, E. (1991) The Educational and Training Needs of the Somali Community in South Glamorgan, unpublished report Welsh Refugee Council

Ahmed, I (1998) Feeling Exclusion? A survey of the Somali community in Lewisham, unpublished report, London Borough of Lewisham.

Bachman, L. F. (1989). The development and use of criterion-referenced tests of language ability in language program evaluation. In R. K. Johnson (Ed.) (1989). The Second Curriculum. Cambridge: Cambridge. University. Press.

Bachman, L. (1990). Fundamental Considerations in Language Testing. Oxford: Oxford University Press.

Bachman, L. \& Palmer, A. (1982). The construct validation of some components of communicative proficiency. TESOL Quarterly 16, 449-465.

Bachman, L. \& Palmer, A. (1989). The construct validation of self-ratings of communicative language ability. Language Testing.

Bachman, L. \& A. Palmer (1996). Language Testing in Practice. Oxford: Oxford University

Batstone, R. (1994) Grammar. Oxford University Press

Brown, H. (1994). Principles of Language Learning and Teaching. Prentice Hall Regents: New Jersey.

Brown, H. D. (1994). Teaching by Principles: An interactive approach to language pedagogy. Englewood Cliffs, NJ: Prentice Hall Regents.

Breen, M.P. (1984a). Process syllabuses for the language classroom. In C.J.Brumfit (Ed.). General English Syllabus Design. ELT Documents No. 118. London: Pergamon Press \& The British Council.

Breen, M.P. (1984b). Process in syllabus design and classroom language learning. In C.J.Brumfit (Ed.). General English Syllabus Design. ELT Documents No. 118. London: Pergamon Press \& the British Council.

Brumfit, C.J. (1981). Notional syllabuses revisited: a response. Applied Linguistics.

Brumfit, C.J. (Ed.). (1984a). General English Syllabus Design. ELT Documents No. 118. London: Pergamon Press \& the British Council.

Brumfit, C.J. (1984b). The Bangalore Procedural Syllabus. English Language Teaching Journal 38/4, $233-241$.

Brumfit, C.J. (1984c). Communicative Methodology in Language Teaching. Cambridge: Cambridge University

Bygate, M. (1987). Speaking. Oxford: Oxford University Press.

Bygate, M. (1988) Units of oral expression and language learning in small group interaction. Applied Linguistics.

Bygate, M. (1996a). Effects of task repetition: appraising the developing language of learners. In J.Willis \& D. Willis (Eds.). (1996). Challenge and Change in Language Teaching. Oxford: Heinemann

Bygate, M. (1996b). The effect of task repetition on language structure and control. Paper presented at AAAL Conference, Chicago. Byram, M. (1986). Cultural studies in foreign-language teaching. Language Teaching.

Bygate, M., Skehan, P. and Swain, M. (2001). Researching Pedagogic Tasks Second Language Learning, Teaching and Testing. England: Pearson Education Limited.

Banafunzi, B. (1996) 'The Education of the Bravanese Community' in Race, Ethnicity and Education, Vol 1 No 1

Brown, H. (1994). Principles of Language Learning and Teaching. Prentice Hall Regents: New Jersey.

Chomsky, N. (2002) On Nature and Language. Cambridge University Press.

Cook, V. J. (1974). English Topics. Oxford: Oxford University Press.

Cook, V.J. (1978a). Second-language learning: a psycho-linguistic perspective. Language Teaching and Linguistics: Abstracts.

Cook, V.J. (1978b). Some Ways of Organising Language. Audio-Visual Journal. 
Cook, V.J. (1985). Language functions, social factors, and second language learning and teaching. International Review of Applied Linguistics.

Cook, V.J. (1994). Linguistics and Second Language Acquisition. London: Macmillan.

Cook, V. (2001) Second Language Learning and Language Teaching ( $3^{\text {rd }}$ Ed). Edward Anorld

Chomsky, N. (1957). Syntactic Structures. The Hague: Mouton.

Cassanelli, L. (1995). Victims and Vulnerable Groups in Southern Somalia, Ottawa: Canadian Immigration Board Research Direcorate.

Cook, V. (1993). Linguistics and Second Language Acquisition. London: The Macmillan Press LTD.

Crookes, G. (1986). Task-based second language acquisition. Technical report no. 4

Carroll, J. B. (1993). Human Cognitive Abilities. Cambridge University Press.

De Angelis, G., \& Selinker, L. (2001). Interlanguage transfer and competing linguistic systems in the multilingual mind. In J. Cenoz, B. Hufeison, \& U. Jessner (Eds.), Cross-linguistic influence in third language acquisition. Tonawanda, NY: Multilingual Matters.

De Angelis, G. (2005). Interlanguage transfer of function words. Language Learning.

Doughty, C. (1991). Second language instruction does make a difference: evidence from an empirical study of second language relativisation. Studies in Second Language Acquisition.

Ellis, N. (1996) .Sequencing in SLA: Phonological memory, chunking and points of order.

Griffiths, D. (2002) Somali and Kurdish Refugees in London, London: Ashgate Press

Grognet, A. G. (1997). Integrating Employment Skills into Adult ESL Instruction. PAIE Q\&A

Haringey, London Borough of (1998) Refugees and Asylum-Seekers in Haringey, London: LB Haringey.

Harmer, J. (1998). How to Teach English. Pearson Education Ltd.

Harmer, J. (1983). The Practice of English Language Teaching. London: Longman.

Hopkins, D. (1989). Evaluation for School Development. Milton Keynes: Open University Press.

Jones, C. and Ali, E. (2000) Meeting the Educational Needs of Somali Pupils in Camden Schools, London: London Borough of Camden available on

Krashen, S.D. (1985). The Input Hypothesis: Issues and Implications. Longman: London and NewYork.

Krashen, S. D. (1982). Principles and Practice in Second Language Acquisition (Language Teaching Methodology). Rowley, MA: Newbury House.

Krashen, S.D. (1985). The Input Hypothesis: Issues and Implications. Longman: London and NewYork.

Krashen, S. D. (1982). Principles and Practice in Second Language Acquisition (Language Teaching Methodology). Rowley, MA: Newbury House.

Kahin, M. (1997) Educating Somali Children in Britain, Stoke on Trent: Trentham Books.

Lightbown, P \& Spada, N. (1999). How Languages are Learned. Oxford University Press: Oxford.

Long, M. (2000). Focus on form in task-based language teaching. In R. Lambert \& E.Shohamy (Eds.), Language policy and pedagogy: Essays in honor of A. Ronald Walton. Philadelphia: John Benjamins.

Mayor, A. (2004). Age, accent and experience in second language acquisition. Clevendon: Multilingual Matters Ltd.

McDonough, J. and McDonough, S. (1997). Research Methods for English Language Teachers. London: Hodder Arnold.

Maslow, A. (1987). Motivation and Personality (3rd Ed). Harper and Row.

Nunan. D. (1987a). Communicative language teaching: Making it work. English Language Teaching Journal.

Nunan, D. (1987b). Guidelines for the Development of Curriculum Resources. Adelaide: National Curriculum Resource Centre.

Nunan, D. (1988a). Learning strategy preferences by EFL teachers in Southeast Asia. Paper presented at the $4^{\text {th }}$ International Conference, Institute of Language in Education, Hong Kong.

Nunan, D. (1988b). Syllabus Design. Oxford: Oxford University Press.

Nunan, D. (1988c). The Learner-centred Curriculum. Cambridge: Cambridge University Press

Nunan, D. (1989). Designing Tasks for the Communicative Classroom. Cambridge: Cambridge University Press.

Palmer, A.S. \& Bachman, L.F. (1981). Basic concerns in test validation. In Alderson \& Hughes (eds.), (1981)

Pennycook, A. (1994). The Cultural Politics of English as an International Language. London:Longman

Pennycook, A. (1997). Cultural alternatives and autonomy. In P. Benson, \& P. Voller. Autonomy and Independence in Language Learning. Harlow: Longman.

Prabhu, N.S. (1987). Second Language Pedagogy. Oxford: Oxford University Press.

Prabhu, N.S. (1984). Procedural syllabuses. In T.E. Read (Ed.). Trends in Language Syllabus Design. Singapore: Singapore University Press/RELC.

Pinker, S. (1994). The Language Instinct. William Morrow

Rutter, J. (2004, forthcoming) Sold short: Education Policy and refugee Children, Buckingham: OUP

Richards, J. (1985). The Context of Language Teaching. Cambridge University press.

Skinner, B. (1957) .Verbal Behavior. Appleton.

Skehan, P. (1998) .A Cognitive Approach to Language Learning. Oxford University Press

Schmidt, R. (1990). The Role of Consciousness in Second Language Learning. Applied Linguistics.

Titmus, C.J. (1989). Lifelong Education for Adults. An International Handbook. Oxford: Perg Amon Press.

Wringe, C. (1989). The Effective Teaching of Modern Languages. Longman: London \& New York.

Willis, J. (1996). A frame-work for Task-based Learning. Pearson education Limited

Wilkins, D. (1976). Notional Syllabuses. Oxford University Press 
Zhou, J. (2003). New Wine in an Old Bottle: Innovative EFL Classrooms in China. IATEFL Issues April - May 2003.

Tower Hamlets, London Borough of (1992) The Somali Community in Tower Hamlets: a demographic survey, London: L.B. Tower Hamlets (council minutes) A useful publisher is Haan Associates http://haanbooks.co.uk. It publishes social and political backgrounds to Somalia as well as bilingual school books.

The Library of Congress Somalia Country Study http://lcweb2.loc.gov/frd/cs/sotoc.html gives detailed background information about Somalia's people and history.

http://www.camden.gov.uk/ccm/content/education/services-for-children-and-parents/camden-lea-support-services/file-storage/meetingneeds-of-somali-research.en 